\title{
The Impact of Human Resource Management (HRM) Practices on Graduate Volunteer Performance: A Case Study of Microfinance Institutions in Cameroon
}

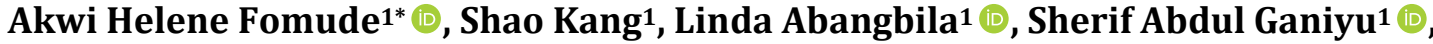 \\ Ngoe Mukete², Megan Emfosi Meena1 \\ ${ }^{1}$ School of Economics and Management, Anhui University of Science and Technology, Huainan, China \\ ${ }^{2}$ College of Economics and Management, Nanjing Agricultural University, Nanjing, China \\ Email: *lenafomude@gmail.com, seeke@qq.com, sabangbila@gmail.com, sherifabdulganiyul@gmail.com, \\ 2364414694@qq.com,megan.meena17@gmail.com
}

How to cite this paper: Fomude, A. H., Kang, S., Abangbila, L., Ganiyu, S. A., Mukete, N., \& Meena, M. E. (2020). The Impact of Human Resource Management (HRM) Practices on Graduate Volunteer Performance: A Case Study of Microfinance Institutions in Cameroon. Open Journal of Business and Management, 8, 2226-2247. https://doi.org/10.4236/ojbm.2020.85136

Received: August 10, 2020

Accepted: September 13, 2020

Published: September 16, 2020

Copyright $\odot 2020$ by author(s) and Scientific Research Publishing Inc. This work is licensed under the Creative Commons Attribution International License (CC BY 4.0).

http://creativecommons.org/licenses/by/4.0/ (c) (i) Open Access

\begin{abstract}
With the present expansion of the global market and its related factors, most organizations are faced with the challenge of ensuring their business processes are efficient and well performing. The implication of this expansion is that managers will have to recruit highly skilled personnel to bridge the gap caused by this globalization by investing more human resources to strategically put the organization in a competitive lead. This study is aimed at analyzing the impact of HRM practices on graduate volunteer performance, a case study of Microfinance institutions in Cameroon. This study presents an overview of how the said HRM practices (performance appraisal, training \& development and motivation \& compensation) could improve or have an impact on the performance of graduate volunteers in an organization, in order for them to eventually achieve their goals and objectives as graduate volunteers while conveying beneficial outcome for both volunteers and the organization thereby enhancing performance. We used a closed-ended questionnaire for our data collection and IBM SPSS 25.0 was used for the analysis. A total of 240 questionnaires were used for the analysis. The results revealed that motivation \& compensation have a greater impact on graduate volunteer performance with a significant beta $(\beta)$ coefficient of 0.388 . The analysis also revealed that all variables in the model are significantly moderated positively. Further analysis shows that the independent variables (performance appraisal, training \& development and motivation \& compensation) are significant predictors of the dependent variable (graduate volunteer performance). This
\end{abstract}


research work adds to the already existing literature in human resource management studies and can be used as a framework for evaluating the performance of employees, volunteers and the company in the long term and also help organizations to select and implement appropriate HRM practices to enable graduate volunteers to achieve their objectives. Future research may involve extending the scope of the study and also increasing the number of variables under the human resource management practices.

\section{Keywords}

HRM Practices, Volunteering Service, Graduate Volunteers, Organizational Performance, Cameroon

\section{Introduction}

Globally, human resources management (HRM) plays a vital role in achieving an innovative and high-quality product or service in an organization. The achievements of an organization widely depend on several significant factors that affect the organization performance. HRM practices such as training and development, compensation, career planning, employee involvement, and performance appraisal encourage the employees to work better thus, increase the performance of the organization (Nabi et al., 2016). These human resource management practices could attract, motivate, propel and retain personnel to ensure the longevity of the organization and positively influence the level of employer and worker commitment. Several organizations invest enormously by placing higher priority on developing human resource to enhance organizational performance (Khan et al., 2011).

To expand the modern knowledge on Human Resource (HR) practices in developing countries, this study was undertaken in microfinance institutions in Cameroon. Microfinance institutions (MFIs) are the rapid growing financial institutions in Cameroon with many products and services available to clients such as financial intermediation, social intermediation, and enterprise development services (Ngwa, 2019). Most microfinance institutions over the world operate through a network of NGOs (ACCION in Latin America, CAMCCUL in Cameroon, etc.) providing funding to low income entrepreneurs in their localities as well as training them to overcome various challenges in their business activities. This microfinance industry of Cameroon has continued to record a steady growth in terms of members and account holders, with current market intelligence estimated at close to 1.4 million account holders (Fotabong, 2012). An estimated $52 \%$ of MFIs in Cameroon are located in urban areas as opposed to just $48 \%$ in rural areas. The distribution of branches of MFIs member institutions is disproportionate with three of the ten regions of Cameroon-the North West, Littoral and Centre regions constituting about $60 \%$, while the South West, the 
West and Extreme North constitute 28\% of the number of MFIs (Fotabong, 2012). MFIs in Cameroon are creating more job opportunities and stabilizing the economy.

As a result of globalization, these MFIs have become profit making institutions so as to be transparent and have access to different sources of financing. These institutions are opening more branch offices and providing opportunities for volunteering services for young graduates to grab some practical knowledge and employment. Volunteering is defined as "long-term or short-term planned, prosocial behaviors that benefit individuals and occur within an organizational setting" (Penner, 2002). But as time goes by the word "volunteers" is been used, understood and defined in different contexts across nations and communities such as corporate and public volunteering.

In recent years, most graduates are being encouraged to accept volunteering service in both private and public sectors so as to gain some practical skills, build-confident and professional experience since no one will want to employ a person with little or no skills such as in micro finance institutions, education, telecoms and healthcare. These volunteers continually play a vital role in the quality and quantity of production of an organization. They perform similar roles with paid employees but they do not receive monetary compensation for their work and consequently, the organization lacks the formal power structures to influence their commitment. Employing HRM practices that could make graduate volunteers feel appreciated, comfortable in their role and connected to other members of the organization may increase volunteering outcomes in this sector. Newton et al. (2014) and Fallon and Rice (2015) held that potential HR practices could positively impact volunteers' commitment and performance in organization. This present study seeks to assess the human resource practices which may enable graduate volunteers (GV) to achieve their goals and evaluate the impacts of the selected human resource practices on graduate volunteer performance in microfinance institutions in Cameroon. Introduction to the study is presented in Section 1 and Section 2 contains the review of literature on human resource management practices. The methodology of the study is presented in Section 3 while the result analysis is indicated in Section 4. Discussion and Conclusion are presented in Sections 5 and 6 respectively.

\section{Literature Review}

Over the decades, increasing competition, globalization and constant change in markets and technology have provided the motivation for reconsidering the way organizations are managed. This reconceptualization laid the foundation for the development of human resource management (HRM), a response to the proposition that efficient management of human resources is essential to improve business outcomes and achieve competitive advantage (Becker \& Huselid, 1998). HRM practices are a process of attracting, motivating, and retaining employees to guarantee the survival of the organization (Hassan, 2016). These policies, 
practices and systems further influence behavior, and performance in an organization. Many organizations refer to HRM as involving "people management" and these HRM practices are designed and implemented in such a way that human capital plays a significant role in achieving the goals of the organization but in this case some HR department always limit their scope to that of employees (permanent staffs) forgetting this group of people are part of human capital. Several important HRM practices support organization business strategy such as analyzing work and designing jobs, determining how many workers with specific knowledge and skills are needed, attracting potential personnel's (recruiting), choosing them (selection), teaching them how to perform their jobs and preparing them for the future (training and development), evaluating their performance (performance appraisal), rewarding them (compensation), and creating a positive work environment (employee relations). HR has a role in facilitating commitment and performance.

In the context of volunteers in an organization, human resource management may constitute a range of activities such as recruitment, appropriate selection, orientation, provision of ongoing training, performance management, recognition, motivation, team work, involving volunteers in relevant decisions making, and providing a supportive work environment (Cuskelly et al., 2006; Alfes et al., 2015). According to Alfes et al. (2015) volunteer management activities could be organized around an ability-motivation-opportunity context. Ability-enhancing human resource activities could help to ensure that volunteers have the requisite skills and knowledge to complete their tasks. Motivation-enhancing human resource activities aim to increase volunteers' intrinsic or extrinsic motivation (Ryan \& Deci, 2000). Opportunity-enhancing activities could focus on creating opportunities for volunteers to use their abilities and act on their motivation. There are few HR practices that are fundamental to the wellbeing of volunteers in organizations in the long term. These HR practices may improve on their results while providing a sportive and conducive working environment such as performance appraisal, motivation, development and training (Dessler, 2007).

Although, there is related literature on HR practices and volunteer management, however, no study has presented a comprehensive evaluation of the human resource practices which may enable graduate volunteers to achieve their goals and examine the main human resource practices which may impact graduate volunteer performance in microfinance institutions in Cameroon. This study bridges that knowledge-gap as it assesses the human resource practices which may enable graduate volunteers to achieve their goals and evaluate the impacts of the selected human resource practices on graduate volunteer commitment and performance in microfinance institutions in Cameroon. This would also create awareness on the importance of the volunteers in non-profit and profit-making organizations. A systematic evaluation of the selected HRM practices could assist both non-profit and profit-making organizations to strength and implement policies to motivate volunteers. Therefore, the HRM 
practices selected for this study include performance appraisal, training and development and motivation.

\subsection{Graduate Volunteer Performance}

First, Rodell (2013) held that volunteerism may contribute positively to organizational performance with reason being that; volunteers will probably have an impact on performance. Some studies have shown how volunteers relates to work-related outcomes depends on volunteer knowledge or skills (Caligiuri et al., 2013; Jones, 2010). Graduate volunteers would value the need or opportunities to acquire practical skills and knowledge through voluntary service (Clary et al., 1998; Penner et al., 2005) and their learning experiences may have impact on their work performance evaluation (Snyder \& Omoto, 2008). Thus, we noticed that HRM practice could have an impact on corporate volunteering participation which may likely enhance organizational performance when volunteers have positive training and learning experiences.

In regards to this, the motivation-based theory of volunteerism claims that volunteers are more motivated to their volunteerism when they noticed it has adequate values for learning and career development (Clary et al., 1998). This is more certain to enhance performance when volunteers gain positive working experiences by acquiring practical skills, knowledge, building self-confidence, social interactions and capabilities they can apply on task or regular work roles (Clary et al., 1998).

When volunteers actually obtain opportunities to develop new knowledge and skills, through training and development, they are likely to impact on the performance of the organization. Newly acquired skills, knowledge, and behaviors represent relatively permanent changes that are required for enhancing performance (Latham \& Saari, 1979).

Positive training and development, performance appraisal, motivation and compensation are also likely to reshape volunteers' self-evaluations and actualization (Kraiger et al., 1993). Acknowledging that they have improved their skills, increased their knowledge, and built self-confidence, graduate volunteers will feel more confidence and committed. Thus, self-enhancement and growth from HRM practice would probably enhance commitment and acquire high levels of performance.

\subsection{Human Resources Management (HRM) Practices}

\subsubsection{Performance Appraisal}

Performance appraisal is a regular and planned evaluation of an employee's performance in his assigned tasks (Hassan, 2016). The underlying purpose of performance appraisal is to know the rate of individual performance, increase motivation and volunteer's self-esteem which could be done monthly or quarterly depending on the institution. This performance appraisal is very necessary to the volunteers as they come with clear objectives, giving them this feedback will help 
them know how well they are moving toward their goals and their level of performance, in most organizations, this activity is not carried out on "volunteers" because they are considered as just volunteers thus making difficult for them to rate themselves. Assessment will help highlight the potential skills and identifying the lack or gap thereby helping to spot out where training and development is needed thus giving them the opportunity to do better or improve on performance and burst up their self-esteem. Gathering this information will help for proper follow up, monitoring and decision making which will provide basis for adjustment and measuring the effectiveness and efficiency, helping in career development, retention, motivation and provide a more conducive, supporting working related environment which is aimed at enhancing their capabilities, opportunities and maximizing their contribution to the organization under the close supervision of their supervisors in the organizations. Rahman (2006) asserted that performance appraisal has been deliberated as the most significant and essential tool for performance management system in an organization. Thus, if this activity is properly, correctly done and supervised, it leads to staff's high level of commitment to their career and organization thus enhancing performance. Thus we formulate our first hypothesis for our study as:

$\mathrm{H}_{1}$ : HRM practice (Performance Appraisal) significantly impact positively on graduate volunteer performance.

\subsubsection{Training \& Development}

Training is the process of coaching, drilling of personnel on specific job-related issues, behavior and bringing out abilities that they will need to perform in a particular given task (McCurley, 2005). Training and development form the core components in most formation of HRM. Aguta and Balcioglu (2015) indicated that presently, most companies try to take a general look at accepting the approach of learning at both individual and organizational levels as a major source of competitive advantage. They further explained that learning has been looked upon as the only strategy which can be used to catch up with the growing changes in technology, world markets, customer expectations and competition. According to Paul and Anantharaman (2003) training can be anything offering learning experience. To make sure that graduate volunteers grab the practical skills, it is imperative to create an appropriate performance level for these volunteers, if possible, on the first day of orientation and training. Nabi et al. (2016) showed that training and development contributes significantly to employee's performance relative to other factors like motivation, technology, management, organizational behavior, and working environment. Some organization offers a lot of training for personnel's as they are passionate to improve their skills and knowledge. Training is highly related to production and productivity of the organization thus if an organization wants to maintain quality, the organization needs to enhance their staff's performance by focusing on training. This can motivate graduate volunteer to achieve higher levels performance. Induction orientation could also be an essential activity for any new member in the com- 
pany so as to familiarize with all its policies, rules and descriptions in the organization. Unfortunately, training is mostly considered as costly and time-consuming and sometimes organizations think that investing in training this group of staffs is not worthwhile as they are considered often as short-term staffs (Hartenian, 2007).

Nevertheless, Cunningham (1999) and Wilson and Pimm (1996) affirm that lack of adequate training is regarded as a key constraint for the effectiveness of voluntary sector (lack of monitoring and close supervisions from supervisor. According Jäger et al. (2007) and Woods (2006) providing continual training support such as providing resources, assisting with access to training or internal training, reimbursing training costs and out-of-pocket expenses, role support, and workload management can benefit graduate volunteers career development and as they add their work force to that of employeesand increase productivity. However, its importance is often considered dispensable. Grossman and Furano (1999) showed that training facilitates commitment and/or retention of volunteers in an organization. Newton et al. (2014) indicated that volunteers with explicit goal and motive had higher levels of commitment when they were provided with learning and development opportunities than volunteers with a weaker understanding motive. This training and development could lead to many volunteers to have the opportunity to apply for internal positions. Therefore we formulate our second hypothesis as:

$\mathrm{H}_{2}$ : HRM practice (Training and development) has a significant positive impact on graduate volunteer performance.

\subsubsection{Motivation and Compensation}

Motivation is a process that stimulates, directs, initiates and maintains human behavior towards attaining goals. It can be a force that stimulates a person eagerness and resistance to pursue a certain course of action. Motivation could be intrinsic or extrinsic. Graduate volunteers are more driven intrinsically because they have clear goals for them to attain new skills and career development. Extrinsic motivation could facilitate this behavior in order to obtain a separable outcome (Ryan \& Deci, 2000). Volunteers are more driven by passion and social interaction rather than monetary but a necessity. On the other hand, compensation is the payment of money to a worker for the physical, mental contribution to the organization they work for which can either be financial and non-financial form. For instance, volunteers in the federal Experience Corps found that stipends improved retention and made possible a more diverse volunteer base (McBride et al., 2011). Compensation both financial and otherwise is of importance to both the volunteers and employees as it influences organization's staff. Both financial and non-financial compensation may be found in the organization. Financial forms are like the bonus, profit sharing plan, travelling allowance and accommodation allowance.

When workers are properly and fairly compensated, it increases organizational performance (Bilal \& Raja, 2011; Aguta \& Balcioglu, 2015). It is important that 
volunteers should be encouraged, supported and their contributions and values should be acknowledged by the organization (Smith \& Lockstone, 2009). For example, in microfinance operations, graduate volunteers often attend to clients and perform different daily job descriptions and transactions such as helping in filling forms, giving directives, opening accounts and replace paid employees when they aren't on duty. They tend to contribute to the growth and performance of this institution.

Working with volunteers entails more attention to their needs in order to impact their commitment and performance. Generally, volunteers do not often receive more attention in organizations. Blanchard (2006) pointed out that volunteers often face some difficulties to perform their roles effectively, and may need a certain form of support from the organization considering that these individuals could be freshly graduates. The use of symbolic rewards and recognition activities is important to improve volunteer commitment and retention (Cnaan \& Cascio 1998; Hager and Brudney, 2004). They appreciate the feelings they are part of the organization, recognition from supervisor and consistent support for daily or basic needs which are essential to help them perform their task such as free meals and transportation could have an impact on their performance. Therefore we formulate our third hypothesis as:

$\mathrm{H}_{3}$ : HRM practice (Motivation and Compensation) significantly impact on graduate volunteer performance.

\section{Research Methodology}

\subsection{Description of Study Area}

This study was carried out in Buea municipality located in Fako Division of South West region of Cameroon. Buea is the capital south west region of Cameroon. This town is located on the eastern slopes $\left(4^{\circ} 10^{\prime} 0^{\prime \prime} \mathrm{N} 9^{\circ} 14^{\prime} 0^{\prime \prime} \mathrm{E}\right)$ of Mount Cameroon some $4100 \mathrm{~m}$ above sea level. The region is characterized by social, political and environmental changes, with an estimated population of some 300,000 inhabitants, the district is diverse with the indigenous Bakweri making up some $30 \%$ and non-indigenous groups (Francophone Cameroon, Nigeria, the Western highlands and other parts of south west region making up 70\% (Mukete \& Monono, 2014). The town has great touristic potential inherent not only from the mountain, but also due to its rich colonial and post-colonial history, being the colonial capital of German Kamerun from 1901 to 1919 and the capital of southern Cameroon from 1949 to 1961. The city also hosts the University of Buea which is the first Anglo-Saxon University in the country. Buea is an educational and trade center, represented by the ever-increasing number of higher institutions as well as commercial banks branch offices. Because of its location at the foot of Mount Cameroon, the climate in Buea tends to be humid, with the neighborhoods at higher elevations enjoying cooler temperatures while the lower neighborhoods experience a hotter climate. Extended periods of rainfall, characterized by incessant drizzle, which can last for days are common during the rainy 
season as are damp fogs, rolling off the mountain into the town below.

\subsection{Sample Size Determination}

We employed the use of close-ended questionnaire for our data collection. A simple random sampling technique was used in selecting our sample from the target population of 650 graduate volunteers in Buea Municipality. A total of 240 out of 248 questionnaires were received and used for our analysis, indicating an effective recovery rate of $97 \%$. We applied Taro Yamane's (1967) sample size determination formula to estimate our sample size. That is:

$$
\begin{gathered}
n=\frac{N}{1+N(e)^{2}} \\
n=\frac{650}{1+650 *(0.05)^{2}}=247.619 \sim 248
\end{gathered}
$$

\subsection{Research Model}

For the purpose of our study, we proposed a research model as shown in Figure 1. As it can be seen from Figure 1, there are three (3) influencing factors of human resource management (HRM) practices impacting on graduate volunteer performance.

\subsection{Data Collection and Model Specification}

Data was collected from April 2020 through July, 2020 using closed-ended questionnaires. The questionnaire was divided in 6 sections, with section one containing items on respondents' demographic characteristics. The other sections contained items pertaining to the selected human resource management practices (Performance Appraisal, Training \& Development and Motivation \&

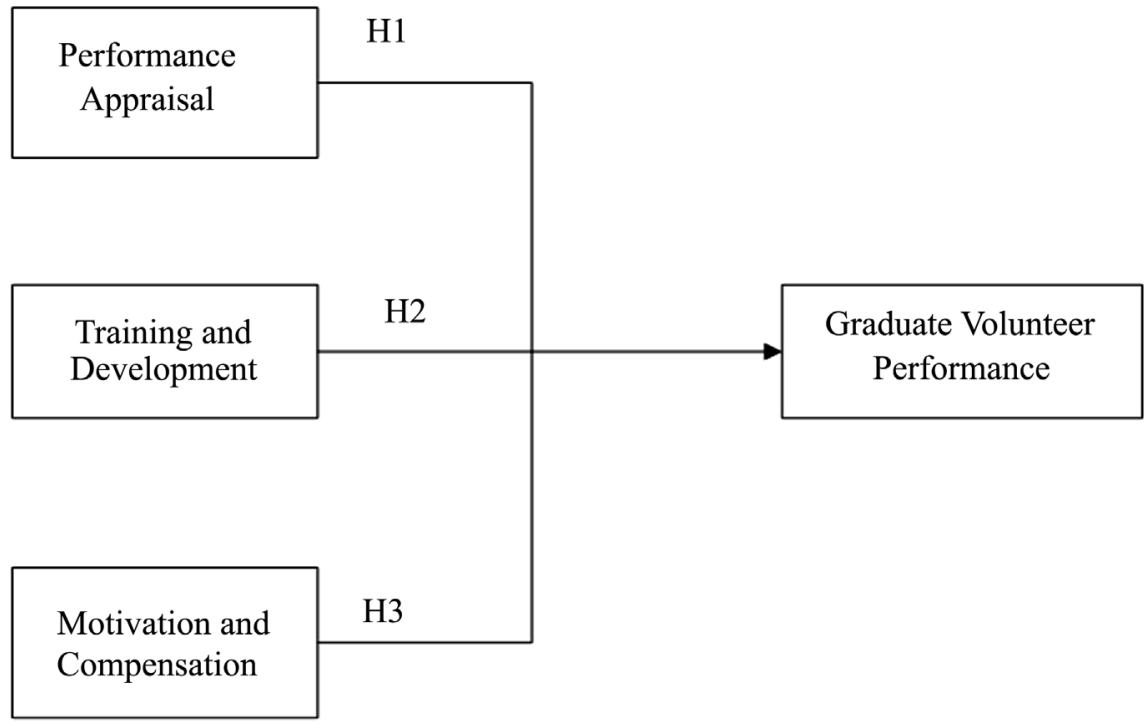

Figure 1. Research model. 
Compensation) and Performance evaluation. The response options for the volunteer's goals in the microfinance consisted of a five-point Likert scale, where 1 = strongly agree, 2 = Agree, 3 = undecided, $4=$ disagree, $5=$ strongly disagree. The questionnaire for our study was adapted from Mira et al., (2019), Qureshi et al., (2007) and modified to fit our current study. A total of 240 respondents were drawn from 10 microfinance institutions through random sampling from a population of 650 volunteers.

IBM SPSS 25.0 was used for the multiple linear regression model analysis to examine the impact of the selected human resource practices on graduate volunteer performance in microfinance institutions. Meanwhile the respondents' demographic characteristics were analyzed using descriptive statistics that included the use of frequencies and percentages. Multiple Linear Regression (MLR) analysis was employed because it allows the relationship between two or more independent variables and one dependent variable to be estimated. Around the globe, several researchers have applied multiple linear regression analysis in Human Resource Management studies (Nabi et al., 2016; Abuhantash, 2019). For the present study, the multiple linear regression model used for estimation is given as:

$$
Y_{i}=\beta_{0}+\beta_{1} \mathrm{PA}+\beta_{2} \mathrm{TD}+\beta_{3} \mathrm{MC}+\varepsilon_{i}
$$

where, $Y_{i}$ is the dependent variable (Graduate Volunteer Performance), $\beta_{0}$ is constant and $\beta_{i}$ are the regression coefficient of the explanatory variables, $\varepsilon_{i}$ is the residual error of regression. The independent variables are, Performance Appraisal (PA), Training and Development (TD) and Motivation and Compensation (MC).

\section{Results}

Data from our study were analyzed using IBM SPSS version 25.0. We performed a descriptive analysis to understand more about the demographic characteristics of respondents under study. A multiple linear regression (MLR) analysis was also performed to evaluate the variables used in our conceptual model.

\subsection{Demographic Information of Respondents}

Descriptive statistics were performed on the data collected from the respondents under study and the results shown in Table 1. According to the results obtained, it shown that majority of our respondents were male and they account for $67 \%$ while the female respondents account for $33 \%$. While majority of them fall between the ages 0 - 20 representing 34\%, followed by those between the ages of 20 - 25 years and 25 - 30 years accounting for $30 \%$ and $8 \%$ respectively. Respondents between the ages of 30 - 35 years account for $6 \%$ while those between the ages of 35 - 40 accounts for $13 \%$. Respondents between the ages of $40-45$ and above 45 years account for $6 \%$ and 3\% respectively. Most of these volunteers educational profiles are bachelor degree holders and they account for $58 \%$ followed by respondents who are holders of the HND degree and Master's degree 
Table 1. Demographic characteristics of respondents.

\begin{tabular}{|c|c|c|c|c|}
\hline Demographic Characteristic & Frequency & Percent & Valid Percent & Cumulative Percent \\
\hline \multicolumn{5}{|l|}{ Gender } \\
\hline Male & 160 & 67.00 & 67.00 & 75.00 \\
\hline Female & 80 & 33.00 & 33.00 & 100.00 \\
\hline Total & 240 & 100.00 & 100.00 & \\
\hline \multicolumn{5}{|l|}{ Educational Background } \\
\hline Bachelor & 140 & 58.00 & 58.00 & 58.00 \\
\hline HND & 50 & 21.00 & 21.00 & 79.00 \\
\hline Masters & 35 & 15.00 & 15.00 & 94.00 \\
\hline Other & 15 & 6.00 & 6.00 & 100.00 \\
\hline Total & 240 & 100.00 & 100.00 & \\
\hline \multicolumn{5}{|l|}{ Age } \\
\hline $0-20$ & 80 & 34.00 & 34.00 & 34.00 \\
\hline $20-25$ & 70 & 30.00 & 30.00 & 64.00 \\
\hline $25-30$ & 20 & 8.00 & 8.00 & 72.00 \\
\hline $30-35$ & 15 & 6.00 & 6.00 & 78.00 \\
\hline $35-40$ & 32 & 13.00 & 13.00 & 91.00 \\
\hline $40-45$ & 15 & 6.00 & 6.00 & 97.00 \\
\hline$>45$ & 8 & 3.00 & 3.00 & 100.00 \\
\hline Total & 240 & 100.00 & 100.00 & \\
\hline \multicolumn{5}{|l|}{ Marital Status } \\
\hline Single & 180 & 75.00 & 75.00 & 75.00 \\
\hline Married & 53 & 22.00 & 22.00 & 97.00 \\
\hline Divorced & 7 & 3.00 & 3.00 & 100.00 \\
\hline Total & 240 & 100.00 & 100.00 & \\
\hline
\end{tabular}

accounting for $21 \%$ and $15 \%$ respectively while other educational levels account for $6 \%$. In response to their marital status, majority of them who do volunteering are the single sex and they account for $75 \%$ of the sample under study. Respondents who are married account for $22 \%$ while $3 \%$ of these volunteers have lost a life partner.

Table 2 represents the area of specialization of graduate volunteers. Analysis focusing on the different areas of human resources practices that volunteers are interested in, indicates that majority of the volunteers focus on talent acquisition and recruitment and they account for $33 \%$ of the respondents, followed by compensation management which represents $25 \%$ of the respondent profile. $15 \%$ of them where focus on general human resource practices while $17 \%$ are focus on training and development whereas $10 \%$ of the respondents focus on other human resource practices not mention in the study. 
Table 2. Area of specialization of respondents.

\begin{tabular}{ccccc}
\hline Area of Specialization & Frequency & Percent & $\begin{array}{c}\text { Valid } \\
\text { Percent }\end{array}$ & $\begin{array}{c}\text { Cumulative } \\
\text { Percent }\end{array}$ \\
\hline Training and Development & 40 & 17.00 & 17.00 & 17.00 \\
Compensation Management & 60 & 25.00 & 25.00 & 42.00 \\
Talent Acquisition and Recruitment & 80 & 33.00 & 33.00 & 75.00 \\
General Human Resource Manager & 35 & 15.00 & 15.00 & 90.00 \\
Other & 25 & 10.00 & 10.00 & 100.00 \\
Total & 240 & 100.00 & 100.00 & \\
\hline
\end{tabular}

From the analysis presented in Table 3, majority of the respondents are of the opinion that their main reason for volunteering is to gain experience and these accounts for $58 \%$ of the respondent profile, followed closely by those who wanted to be intergraded in the work milieu and this accounts for $45 \%$ of the respondent profile. $15 \%$ of these respondents volunteered in order to build their self-confidence, the other $8 \%$ volunteered because of other reasons of which some were personal to the respondents.

\subsection{Reliability of the Study}

Hinton (2004) said that reliability always measures how well items in a questionnaire answer the respective questions and more importantly how well these items fit well together. To measure how reliable our questionnaire used in the survey is, we used SPSS 25.0 to estimate the Cronbach's alpha coefficient to measure the internal consistency of our questionnaire. Cronbach's alpha is the most widely used reliability statistic employed by many researchers to measure internal consistency reliability (Spiliotopoulou, 2009; Devon et al., 2007). Cronbach $\alpha$ coefficient values above 0.70 indicates a good reliability (Bland \& Altman, 1997). Result in Table 4 indicates that the estimated Cronbach $\alpha$ value ranged between $0.718-0.856$ for all scale of measurement variables implying a high correlation between the items and the questions, consequently the questionnaire used for our study was consistently reliable

\subsection{Construct Validity}

In order to get Kaiser-Meyer-Olkin (KMO) and Bartlett's Test of Sphericity measures, we performed a factor analysis to test how accurate are the measurement results. KMO measure is used to determine if the answers given to the questionnaire for our survey were adequate or not. Kaiser (1974) recommended a KMO estimate of 0.5 as the minimum for a satisfactory factor analysis. Results from Table 5 indicate that the minimum KMO value was achieved with a value of 0.759 , implying the adequacy of our sampling.

Bartlett's Test of Sphericity measures the strength or degree of association among the variables under study. The null hypothesis for this test is that "The 
Table 3. Respondents reason for volunteering.

\begin{tabular}{ccccc}
\hline Reason for Volunteering & Frequency & Percent & $\begin{array}{c}\text { Valid } \\
\text { Percent }\end{array}$ & $\begin{array}{c}\text { Cumulative } \\
\text { Percent }\end{array}$ \\
\hline Building self confidence & 35 & 15.00 & 15.00 & 15.00 \\
To gain experience & 140 & 58.00 & 58.00 & 73.00 \\
Integrated in the working milieu & 45 & 19.00 & 19.00 & 92.00 \\
Other & 20 & 8.00 & 8.00 & 100 \\
Total & 240 & 100.00 & 100.00 & \\
\hline
\end{tabular}

Table 4. Reliability of constructs.

\begin{tabular}{ccc}
\hline Variable & No of Items measured & Cronbach's Alpha \\
\hline Graduate Volunteer Performance & 3 & 0.778 \\
Performance Appraisal & 10 & 0.856 \\
Motivation and Compensation & 7 & 0.718 \\
Training and Development & 11 & 0.824
\end{tabular}

Table 5. Construct validity.

\begin{tabular}{ccc}
\hline Test & Measure & Estimate \\
\hline Kaiser-Meyer-Olkin Measure of Sampling Adequacy & & 0.759 \\
Bartlett's Test of Sphericity & Approx. Chi-square & 5067.591 \\
& df & 465 \\
& Sig. & 0.00 \\
\hline
\end{tabular}

correlation matrix is an identity matrix". Results from the analysis as shown in Table 5 indicates a statistical significance for the Bartlett's test with a P-value of 0.00 and an approx. chi-square of 5067.591, consequently, we reject the null hypothesis that the correlation matrix is an identity matrix.

\subsection{Correlation Matrix}

Pearson's correlation coefficient statistic measures the statistical relationship between two continuous or quantitative variables (Rodgers \& Nicewander, 1988). The Pearson's correlation tests the null hypothesis that "There is no linear relationship between the two variables $(\rho=0)$ " and alternative hypothesis "There is a linear relationship between the two variables $(\rho \neq 0)$ ". The correlation coefficient ranges between -1 and +1 . A correlation coefficient of zero indicates no linear relationship exists between the two variables under study and correlation coefficient of -1 or +1 indicates a perfect linear association. The general criteria for judging the magnitude and direction of the correlation coefficients according to Mukaka (2012), and Overholser \& Sowinski (2008) are as follows: a correlation coefficient between 0.00 - 0.10 indicates negligible correlation, between $0.10-0.39$ indicates weak correlation, between $0.40-0.69$ indi- 
cates Moderate correlation, and between 0.70 - 0.89 indicates Strong correlation and a value between $0.90-1.00$ indicates a Very strong correlation. Result in Table 6 indicates that all the correlation coefficients are significantly different from zero $(0.316-0.652)$ indicating a form of association between the variables and also the relationships between the variables are statistically significantly since all the $P$-values are less than 0.05 .

\subsection{Multiple Linear Regression (MLR) Analysis}

Table 7 shows the model summary of our analysis. The result indicates a multiple coefficient $(R)$ value of 0.837 and a coefficient of determination $\left(R^{2}\right)$ value of 0.789 . The coefficient of determination explains the degree of variation of the dependent variable by the predictor variables. This means that about $79 \%$ of the variation in our dependent variable (Graduate Volunteer Performance) was explained by our predictor variables (Performance Appraisal, Training \& Development and Motivation \& Compensation) while the rest of the variations are explained by the error term. The analysis also revealed a significant F-Test value (F-test $=20.198, P<0.05$ ), which is an indication of model fit. The result also shows a moderate autocorrelation among the predictor variables with a Durbin-Watson value of 1.945. Field (2009) asserted that Durbin-Watson Values less than 1 and more than 3 are a definite cause for concern. This means that the autocorrelation in our model is relatively normal.

Table 6. Means, standard deviations and correlations of variables.

\begin{tabular}{|c|c|c|c|c|c|c|}
\hline \multirow{2}{*}{ Variable } & \multicolumn{6}{|c|}{ Correlation Matrix } \\
\hline & Mean & Std. Dev & 1 & 2 & 3 & 4 \\
\hline Graduate Volunteer Performance & 17.26 & 3.19 & 1 & & & \\
\hline Performance Appraisal & 56.33 & 8.19 & $\begin{array}{l}0.472^{\star *} \\
(0.000)\end{array}$ & 1 & & \\
\hline Training \& Development & 39.51 & 5.82 & $\begin{array}{l}0.424^{\star *} \\
(0.000)\end{array}$ & $\begin{array}{l}0.428^{\star *} \\
(0.000)\end{array}$ & 1 & \\
\hline Motivation \& Compensation & 54.63 & 7.80 & $\begin{array}{l}0.521^{\star *} \\
(0.000)\end{array}$ & $\begin{array}{l}0.652^{\star *} \\
(0.000)\end{array}$ & $\begin{array}{l}0.316^{* *} \\
(0.000)\end{array}$ & 1 \\
\hline
\end{tabular}

${ }^{* * *}$ Correlation significant at the 0.01 (2-tailed) and Sig. values in parenthesis.

Table 7. Model summary.

\begin{tabular}{cc}
\hline Measure & Estimate \\
\hline $\mathrm{R}$ & 0.837 \\
R-square & 0.789 \\
Adjusted R-square & 0.678 \\
Standard Error of estimate & 2.86469 \\
F-change & 20.198 \\
Sig. F & 0.000 \\
Durbin-Watson & 1.945 \\
\hline
\end{tabular}

Dependent variable: Graduate volunteer performance; Predictors: Constant, training \& development, motivation \& compensation, performance appraisal. 
Result from Table 8 indicates that our regression model is statistically significant (Sig. value -0.00) when the independent variables are regressed on the dependent variable. This further implies that, our independent variables (Performance Appraisal, Training \& Development and Motivation \& Compensation) are significant predictors of our dependent variable (Graduate Volunteer Performance).

The result in Table 9 shows the estimates or coefficients of our regression analysis. The result revealed that all the variables in the model are statistically significant at the $95 \%$ confidence interval and impact positively on the dependent variable. The $P$-values of all variables are less than 0.05 ; furthermore the $\mathrm{T}$-values for all the variables are greater than the critical value of 1.96 indicating that our coefficient estimates are statistically significantly different from zero at the $95 \%$ confidence level. To examine the presence of Multicollinearity in our model, we estimated the Tolerance and Variance Inflation Factor (VIF) measures. Daoud, (2017) recommended that a tolerance value less than 0.10 indicates the presence of Multicollinearity. Ringle et al., (2015) also recommended a minimum acceptable value of VIF to be 5. Result in Table 9 indicates no presence of Multicollinearity in our model since values for Tolerance are greater than 0.10 and VIF values are also less than the minimum acceptable value of 5 . The fitted model based on the coefficient estimates in Table 9 is presented in Equation (2):

$$
\mathrm{GVP}=7.901+0.207(\mathrm{PA})+0.388(\mathrm{MC})+0.168(\mathrm{TD})
$$

where dependent variable: Graduate volunteer performance (GVP)

Predictor Variables: Performance Appraisal (PA)

Motivation \& Compensation (MC)

Training \& Development (TD)

Table 8. ANOVA.

\begin{tabular}{cccccc}
\hline Model & Sum of squares & df & Mean square & F & Sig \\
\hline Regression & 497.256 & 3 & 165.752 & 20.198 & 0.000 \\
Residual & 1936.728 & 236 & 8.206 & & \\
Total & 2433.983 & 239 & & &
\end{tabular}

Dependent variable: Graduate volunteer performance; Predictors: Constant, training \& development, motivation \& compensation, performance appraisal.

Table 9. Coefficient estimates.

\begin{tabular}{cccccc}
\hline Variables & Estimate & T Value & Sig. Value & Tolerance & VIF \\
Constant & 7.901 & 4.961 & 0.001 & & \\
Performance Appraisal & 0.207 & 2.572 & 0.011 & 0.520 & 1.923 \\
Motivation \& Compensation & 0.388 & 6.033 & 0.000 & 0.814 & 1.228 \\
Training \& Development & 0.168 & 2.186 & 0.030 & 0.573 & 1.744 \\
\hline
\end{tabular}

Dependent variable: Graduate volunteer performance. 


\subsection{Hypothesis Testing}

The result for hypothesis testing is shown in Table 9.

$\mathrm{H}_{1}$ : HRM practice (Performance Appraisal) significantly impact positively on graduate volunteer performance.

Performance Appraisal was estimated to have a beta coefficient ( $\beta$ ) of 0.207 indicating a $20.7 \%$ impact on graduate volunteer performance. This estimate was statistically significant at the $95 \%$ confidence interval with a $P$-value of 0.011 (P $<0.05)$. The T-value for performance appraisal was also estimated to be 2.572 . This value was also statistically significant since the estimated value is greater than the critical value of 1.96 at the $95 \%$ confidence level. Performance appraisal is also found to have a significant moderate association with graduate volunteer performance $(\rho=0.472)$. This indicates that an increase in performance appraisal of volunteers will increase performance levels for both volunteer and organizational, all other factors constant. Rahman (2006) said that performance appraisal is a fundamental and efficient tool for performance management system in most organizations. Therefore we accept our hypothesis and conclude that Organizations that use performance appraisal methods to measure performance of volunteers are likely to achieve a competitive advantage and positively impact on the performance of graduate volunteers.

$\mathrm{H}_{2}$ : HRM practice (Training and development) has a significant positive impact on graduate volunteer performance.

Training and development is an essential component of human resource management practices that involve the developing the talents of employees. The result in Table 9 shows that, Training and development have a significant positive impact on graduate volunteer performance $(\beta=0.168, P$-value $=0.030)$. The estimated T-ratio was 2.186 , which is also statistically significant since the estimated value is greater than the critical value of 1.96 at the $95 \%$ confidence level. The correlation matrix table also indicated a significant positive moderate association between training and development and graduate volunteer performance $(\rho=0.424)$. This implies that, as graduate volunteers are being given the opportunity to develop and build on their existing knowledge, they tend to perform better when they are being tasked thereby increasing their performance impact in their organization. The long term results of this training and career or goals development is enhanced organizational performance (Nabi et al., 2016; Woods, 2006). Based on the analysis, we accept our second hypothesis and conclude that, investing in the training and development of graduate volunteers will increase their performance in the organization and therefore increase organizational performance.

$\mathrm{H}_{3}$ : HRM practice (Motivation and Compensation) significantly impact on graduate volunteer performance.

Motivation \& Compensation is an essential component of human resource management practices and plays a pivotal role in enhancing employee performance and organizational performance. Result in Table 9 indicates a significant 
positive impact of motivation \& compensation on graduate volunteer performance $(\beta=0.388, P$-value $=0.000)$. This variable was found to predict more on graduate volunteer performance than the rest of the variables by $38.8 \%$. The strength of the association between motivation and compensation was further indicated by the correlation matrix in Table 6 , which indicated a significant moderate positive association $(\rho=0.521)$. This means that organizations that implement motivation and compensation techniques or approaches in their companies are likely to achieve organizational performance since volunteers would want to work more because they will be motivated or compensated for the extra task done. This eventually translate into an enhance performance on the part of the volunteer and the organization (Bilal \& Raja, 2011; Aguta \& Balcioglu, 2015). Consequently, we accept our third hypothesis and conclude that motivation \& compensation as a human resource management practice is likely to increase the performance of graduate volunteers and enhance competitive advantage of organizations.

\section{Discussion}

The result in Table 8 shows that Human resource practices (Performance appraisal, Training \& development and Motivation \& compensation) has a positive effect on Graduate volunteer performance in Microfinance Institutions in Cameroon (model sig. value-0.000). This means that an increase in human resource management practices will lead to an increase in volunteers' performance and for that matter, an increase in organizational performance. Result in Table 9 also indicates that motivation and compensation have a great effect on the outcome of volunteers. This motivation can be in the form of cash or other capacity building or career development opportunities. Institutions that place high priority in motivating its volunteers are likely to bring out the best in them and therefore harnessing their potentials to enhance organizational performance. The correlation analysis in Table 6 shows that motivation \& compensation has a high correlation with performance appraisal $(\rho=0.652, \mathrm{P}<0.05)$. This means that, as graduate volunteers are being motivated and compensated for tasks assigned, they tend to perform extremely better thereby scoring high remarks during performance appraisal evaluations. Training \& Development was also seen to have a positive impact on graduate volunteers' performance. This means that organizations that invest in the training and career development of graduate volunteers are likely to achieve a competitive advantage and overall organizational performance. As these volunteers' are being trained, they tend to apply their new knowledge and ideas to the working environment of the company. These innovative ideas of volunteers' may be useful in enhancing organizational performance in the long term.

Performance appraisal has a positive impact on graduate volunteer performance with a significant correlation coefficient $(\rho=0.472, P<0.05)$. This may be attributed to the fact that, as volunteers are being evaluated and remarks giv- 
en for tasks done, they put more agility to outperform the previous remark. This put volunteers on their toes to do their tasks very with perfection. With this level of zeal among volunteers, they tend to perform better and increasing organizational performance.

\section{Conclusion}

The purpose of this current study is to examine the impact of Human Resource Management practices (Performance Appraisal, Training \& Development and Motivation \& Compensation) on Graduate volunteer outcome, a case study of Microfinance in Buea Municipality in South West Region of Cameroon. Results from this study showed that human resource management practices (Performance appraisal, Training \& Development and Motivation \& Compensation) have a positive impact on graduate volunteers' performance, the more this activity (HRM Practices) is provided, it will yield to high performance and also self-actualization. The study also found that majority of graduate volunteers have a positive view about volunteering such as building self-confidence, getting employment, etc. It exhibits a positive impact on volunteering service, and also increases the productivity of the organization. Researchers are further recommended to study the impact of HRM practices volunteerism. More studies are needed to develop and test propositions regarding HR's impact on volunteer's performance in an organization.

\section{Recommendations}

1) We recommend that human resource management practices should be applied to volunteers in order for them to obtain their career goals, proper fellow up should be done by supervisors when tasking graduate volunteers. Also, an organized system could be introduced by institutions or local government where every graduate could actually build up a profile and gain practical experience after their graduation (graduate service) irrespective of the organization. For instance, the local government could create a platform whereby all graduates are entitled to have practical knowledge of what they learnt, it could be in a form of graduate service that runs from 6 months to a year as it is done in some African countries such as Ghana, Nigeria, etc.

2) We also recommend that microfinance institutions in Cameroon should invest more providing capacity building and self-confidence programs such as seminars, internal training for volunteers to do their tasks competently since the result analysis indicated that majority of the respondents undertake volunteering services to gain working experience. A large number of the respondents also indicated that their area of specialization is talent acquisition and recruitment, since no employer will want to employ someone with no practical skills; therefore, we recommend that microfinance institution in Cameroon to implement structures that are aimed at harnessing the skills and ideas of volunteers to enhance performance. 


\section{Limitations and Future Research Directions}

Although this study has revealed some significant findings and insights relating to HRM practices, there are some limitations that can be addressed in future studies. This research was based on Buea municipality, south west region of Cameroon and not the entire country. This study was limited to four variables. Future researchers may expand the number of variables and sample size to cover a wider area. This would enhance generalizability of the analysis to represent the entire population under study. The assessment tool used in this study can be employed by future researchers in the field of HRM who may conclude corroborating or opposing results or findings.

\section{Conflicts of Interest}

The authors declare no conflict of interest regarding the publication of this paper.

\section{References}

Abuhantash, A. (2019). The Impact of Human Resource Management Practices on Job Performances: A Case Study of Bank of Texas. Human Resource Management Research, 6, 45-54.

Aguta and Balcioglu (2015). The Impact of Human Resource Management Practices on Organizational Performance: A Case of Private Banks in North Cyprus.

Alfes, K., Shantz, A., \& Saksida, T. (2015). Committed to Whom? Unraveling How Relational Job Design Influences Volunteers' Turnover Intentions and Time Spent Volunteering. Voluntas: International Journal of Voluntary and Nonprofit Organizations, 26, 2479-2499. https://doi.org/10.1007/s11266-014-9526-2

Bilal, J., \& Raja, N. S. (2011). Impact of Compensation, Performance Evaluation and Promotion Practices on Government Employee Performance vs Private Employee Performance. Interdisciplinary Journal of Contemporary Research in Business, 3, 907-913.

Bland, J. M., \& Altman, D. G. (1997). Statistics Notes: Cronbach’s Alpha. BMJ, 314, 572. https://doi.org/10.1136/bmj.314.7080.572

Caligiuri, P., Mencin, A., \& Jiang, K. (2013). Win-Win-Win: The Long-Term Influence of Company-Sponsored Volunteerism Programs. Personnel Psychology, 66, 825-860. https://doi.org/10.1111/peps.12019

Clary, E. G., Snyder, M., Ridge, R. D., Copeland, J., Stukas, A. A., Haugen, J., \& Miene, P. (1998). Understanding and Assessing the Motivations of Volunteers: A Functional Approach. Journal of Personality and Social Psychology, 74, 1516-1530. https://doi.org/10.1037/0022-3514.74.6.1516

Cnaan, R. A., \& Cascio, T. A. (1998). Performance and Commitment. Journal of Social Service Research, 24, 1-37. https://doi.org/10.1300/J079v24n03 01

Cunningham, I. (1999). Human Resource Management in the Voluntary Sector: Challenges and Opportunities. Public Money Manage, 19, 19-25. https://doi.org/10.1111/1467-9302.00161

Cuskelly, G., Taylor, T., Hoye, R., \& Darcy, S. (2006). Volunteer Management Practices and Volunteer Retention: A Human Resource Management Approach. Sport Management Review, 9, 141-163. https://doi.org/10.1016/S1441-3523(06)70023-7 
Daoud, J. I. (2017). Multicollinearity and Regression Analysis. Journal of Physics: Conference Series, 949, Article ID: 012009. https://doi.org/10.1088/1742-6596/949/1/012009

Dessler, G. (2007). Human Resource Management. New Delhi: Prentice Hall of India Private Limited.

Devon, H. A., Block, M. E., Moyle-Wright, P., Ernst, D. M., Hayden, S. J., Lazzara, D. J., Savoy, S. M., \& Kostas-Polston, E. (2007). A Psychometric Toolbox for Testing Validity and Reliability. Journal of Nursing Scholarship, 39, 155-164. https://doi.org/10.1111/j.1547-5069.2007.00161.x

Fallon, B. J., \& Rice, S. M. (2015). Investment in Staff Development within an Emergency Services Organisation: Comparing Future Intention of Volunteers and Paid Employees. The International Journal of Human Resource Management, 26, 485-500. https://doi.org/10.1080/09585192.2011.561222

Field, A. P. (2009). Discovering Statistics Using SPSS: And Sex and Drugs and Rock " $n$ " Roll(3rd ed.). London: Sage.

Fotabong, L. A. (2012). The Microfinance Market of Cameroon-Analyzing Trends and Current Development. SSRN 2007912. https://doi.org/10.2139/ssrn.2007912

Grossman, J. B., \& Furano, K. (1999). Making the Most of Volunteers. Law and Contemporary Problems, 62, 199-218. https://doi.org/10.2307/1192273

Hartenian, L. S. (2007). Nonprofit Agency Dependence on Direct Service and Indirect Support Volunteers: An Empirical Investigation. Nonprofit Management and Leadership, 17, 319-334. https://doi.org/10.1002/nml.152

Hassan, S. (2016). Impact of HRM on Employee's Performance. International Journal of Academic Research in Accounting, Finance and Management Sciences, 6, 15-22. https://doi.org/10.6007/IJARAFMS/v6-i1/1951

Jäger, U., Schmidt, K., \& Beyes, T. (2007). Leading without Formal Power. In 6th Workshop on the Challenges of Managing the Third Sector.

Jones, D. A. (2010). Does Serving the Community Also Serve the Company? Using Organizational Identification and Social Exchange Theories to Understand Employee Responses to a Volunteerism Program. Journal of Occupational and Organizational Psychology, 83, 857-878. https://doi.org/10.1348/096317909X477495

Kaiser, H. F. (1974). An Index of Factorial Simplicity Psychometrics. Psychometrika, 39, 31-36. https://doi.org/10.1007/BF02291575

Khan, M. A. (2011). Effects of Human Resource Management Practices on Organizational Performance-An Empirical Study of Oil and Gas Industry in Pakistan. European Journal of Economics, Finance and Administrative Science, 24, 158-175.

Kraiger, K., Ford, J. K., \& Salas, E. (1993). Application of Cognitive, Skill-Based, and Affective Theories of Learning Outcomes to New Methods of Training Evaluation. Journal of Applied Psychology, 78, 311-328. https://doi.org/10.1037/0021-9010.78.2.311

Latham, G. P., \& Saari, L. M. (1979). Importance of Supportive Relationships in Goal Setting. Journal of Applied Psychology, 64, 151-156. https://doi.org/10.1037/0021-9010.64.2.151

McBride, A. M., Gonzales, E., Morrow-Howell, N., \& McCrary, S. (2011). Stipends in Volunteer Civic Service: Inclusion, Retention, and Volunteer Benefits. Public Administration Review, 71, 850-858. https://doi.org/10.1111/j.1540-6210.2011.02419.x

McCurley, S. (2005). Keeping the Community Involved. In R. D. Herman et al. (Eds.), 
The Jossey-Bass Handbook of Nonprofit Leadership \& Management (pp. 587-623). San Francisco, CA: Jossey-Bass.

Mira, M. S., Choong, V. Y., \& Thim, K. C. (2019). The Effect of HRM Practices and Employees' Job Satisfaction on Employee Performance. Management Science Letters, 9, 771-786. https://doi.org/10.5267/j.msl.2019.3.011

Mukaka, M. M. (2012). Statistics Corner: A Guide to Appropriate Use of Correlation Coefficient in Medical Research. Malawi Medical Journal, 24, 69-71.

Mukete, B., \& Monono, S. (2014). Assessing the Impact of Consumer Behavior on Food Security in South West Cameroon. Journal of Food Security, 2, 87-91.

Nabi, Md. N., Syduzaman, Md., \& Munir, Md. S. (2016). The Impact of Human Resource Management Practices on Job Performances: A Case Study of Dhaka Bank Pvt. Ltd., Bangladesh. Human Resource Management Research, 6, 45-54.

Newton, C., Becker, K., \& Bell, S. (2014). Learning and Development Opportunities as a Tool for the Retention of Volunteers: A Motivational Perspective. Human Resource Management Journal, 24, 514-530. https://doi.org/10.1111/1748-8583.12040

Ngwa, G. (2019). The Role of Micro Finance Institution in the Development of SME in Cameroon. Bamenda: Agyati Cooperative Credit Union Limited (Agyaccul).

Overholser, B. R., \& Sowinski, K. M. (2008). Biostatistics Preview: Part 2. Nutrition in Clinical Practice, 23, 76-84. https://doi.org/10.1177/011542650802300176

Paul, A. K., \& Anantharaman, R. N. (2003). Impact of People Management Practices on Organisational Performance. International Journal of Human Resource Management, 14, 1246-1266. https://doi.org/10.1080/0958519032000145648

Penner, L. A. (2002). Dispositional and Organizational Influences on Sustained Volunteerism: An Interactionist Perspective. Journal of Social Issues, 58, 447-467.

https://doi.org/10.1111/1540-4560.00270

Penner, L. A., Dovidio, J. F., Piliavin, J. A., \& Schroeder, D. A. (2005). Prosocial Behavior: Multilevel Perspectives. Annual Review of Psychology, 56, 365-392.

https://doi.org/10.1146/annurev.psych.56.091103.070141

Qureshi, M., Tahir Hijazi, T., Syed Ramey, I., \& Mohammad (2007). Impact of Human Resource Management Practices on Pakistan Organizations. Journal of Business and PolicyResearch, 3, 128-138.

Ringle, C. M., Wende, S., \& Becker, J.-M. (2015). SmartPLS 3. Bönningstedt: SmartPLS. http://www.smartpls.com

Rodell, J. B. (2013). Finding Meaning through Volunteering: Why Do Employees Volunteer and What Does It Mean for Their Jobs? Academy of Management Journal, 56, 1274-1294. https://doi.org/10.5465/amj.2012.0611

Rodgers, J. L., \& Nicewander, W. A. (1988). Thirteen Ways to Look at the Correlation Coefficient. The American Statistician, 42, 59-66. https://doi.org/10.1080/00031305.1988.10475524

Ryan, R., \& Deci, E. (2000). Self-Determination Theory and the Facilitation of Intrinsic Motivation, Social Development, and Well-Being. American Psychologist, 55, 68-78. https://doi.org/10.1037/0003-066X.55.1.68

Smith, K. A., \& Lockstone, L. (2009). Involving and Keeping Event Volunteer; Management Insights from Cultural Festival. In T. Baum, M. Deery, C. Hanlon, L. Lockstone, \& K. Smith (Eds.), People and Work in Events and Conventions; a Research Perspective (pp. 154-167). Cambridge, MA: CAB International.

https://doi.org/10.1079/9781845934767.0154 
Snyder, M., \& Omoto, A. (2008). Volunteerism: Social Issues, Perspectives and Social Policy Implications. Social Issues and Policy Review, 2, 1-36.

https://doi.org/10.1111/j.1751-2409.2008.00009.x

Spiliotopoulou, G. (2009). Cronbach's Alpha and Paediatric Assessment in Occupational Therapy. Australian Occupational Therapy Journal, 56, 150-155.

https://doi.org/10.1111/j.1440-1630.2009.00785.x

Wilson, A., \& Pimm, G. (1996). The Tiranny of the Volunteer: The Care and Feeding of Voluntary Workforce. Management Decision, 34, 24-40.

https://doi.org/10.1108/00251749610115134

Woods, T. B. (2006). The Rhetoric of Volunteerism: Strategies to Recruit and Retain Volunteers in Nonprofit Organizations. Atlanta, GA: Georgia State University.

Yamane, T. (1967). Statistics, an Introductory Analysis (2nd ed.). New York: Harper and Row. 